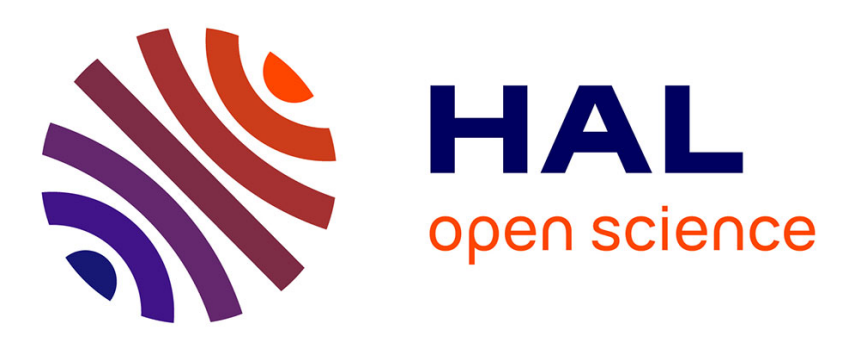

\title{
High Magma Storage Rates Before the 1983 Eruption of Kilauea, Hawaii
}

\author{
Valérie Cayol, James H. Dieterich, Arnold T. Okamura, Asta Miklius
}

\section{To cite this version:}

Valérie Cayol, James H. Dieterich, Arnold T. Okamura, Asta Miklius. High Magma Storage Rates Before the 1983 Eruption of Kilauea, Hawaii. Science, 2000. hal-03049436

\section{HAL Id: hal-03049436 https://hal.science/hal-03049436}

Submitted on 9 Dec 2020

HAL is a multi-disciplinary open access archive for the deposit and dissemination of scientific research documents, whether they are published or not. The documents may come from teaching and research institutions in France or abroad, or from public or private research centers.
L'archive ouverte pluridisciplinaire HAL, est destinée au dépôt et à la diffusion de documents scientifiques de niveau recherche, publiés ou non, émanant des établissements d'enseignement et de recherche français ou étrangers, des laboratoires publics ou privés. 


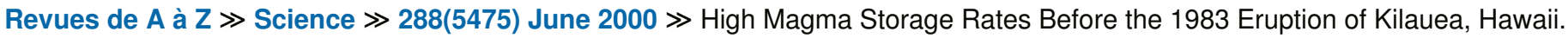

\title{
Science
}

Numéro : Volume 288(5475), 30 June 2000, pp 2343-2346

Copyright : Copyright (C) 2000 by the American Association for the Advancement of Science

Type de publication : [Research: Reports]

ISSN : 0036-8075

Accès : 00007529-200006300-00011

[Research: Reports]

\section{High Magma Storage Rates Before the 1983 Eruption of Kilauea, Hawaii}

\author{
Cayol, Valérie ${ }^{1^{*} \dagger}$; Dieterich, James H. ${ }^{1}$; Okamura, Arnold T. ${ }^{2}$; Miklius, Asta ${ }^{2}$
}

\section{Informations sur l'auteur}

${ }^{1}$ U.S. Geological Survey, 345 Middlefield Road, MS 977, Menlo Park, CA 94025, USA. U.S. Geological Survey, Hawaiian Volcano Observatory, HI 96718, USA.

*Present address: Laboratoire Magmas et Volcans-UMR 6524, 5 rue Kessler, 63000 Clermont-Ferrand, France. †To whom correspondence should be addressed. E-mail: cayol@opgc.univ-bpclermont.fr

1 March 2000; accepted 17 May 2000

\section{Abstract}

After a magnitude 7.2 earthquake in 1975 and before the start of the ongoing eruption in 1983, deformation of Kilauea volcano was the most rapid ever recorded. Three-dimensional numerical modeling shows that this deformation is consistent with the dilation of a dike within Kilauea's rift zones coupled with creep over a narrow area of a low-angle fault beneath the south flank. Magma supply is estimated to be 0.18 cubic kilometers per year, twice that of previous estimates. The 1983 eruption may be a direct consequence of the high rates of magma storage within the rift zone that followed the 1975 earthquake.

Kilauea volcano is characterized by rapid deformation and intense seismic activity (Fig. 1). In 1975, the magnitude $(M) 7.2$ Kalapana earthquake caused the south flank of the volcano to move seaward by as much as 8 m (1). After the Kalapana earthquake and before the onset of the Pu'u O'o eruption in 1983, high rates of deformation were recorded, and magmatic activity of the volcano was predominately intrusive (2). Since 1983, the volcano has been almost continuously eruptive. This change from intrusive to eruptive activity was associated with a decrease of extension rates across Kilauea caldera from 25 to $4 \mathrm{~cm} / y e a r(3)$. This report addresses the deformation of Kilauea's rift system and flanks for the period between the 1975 earthquake and the 1983 eruption. 


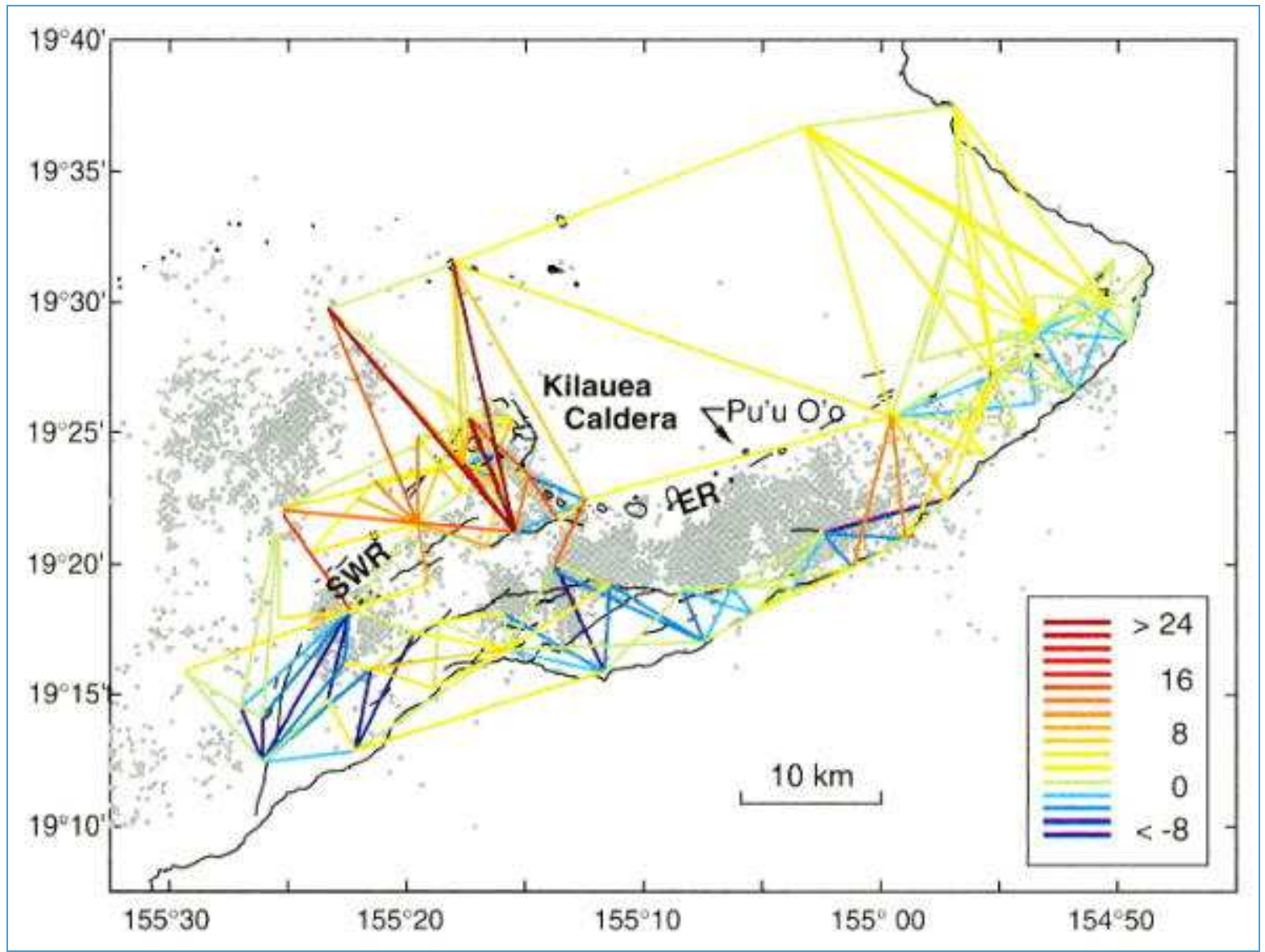

Fig. 1. Map of Kilauea volcano, showing rates of relative displacements (in $\mathrm{cm} / \mathrm{year}$ ) recorded by trilateration between 1976 and 1982. Trilateration measurements are estimated to have a fixed error of $1 \mathrm{~cm}$ and a scale error of 1 part per million (31). Locations of $M>=2$ earthquakes (gray dots) recorded from 1976 to 1982 are also shown. ER, east rift zone; SWR, southwest rift zone.

Geodetic and seismological observations $(4,5)$ indicate that magma rises from the mantle through a conduit located below Kilauea summit before being supplied to the rift zones. Magma is stored within these rift zones, as evidenced from petrologic (6) and geophysical studies (7,8). Supply of magma to the rift zones is sometimes accompanied by shallow ( 1 to $4 \mathrm{~km}$ ) swarms of earthquakes corresponding to the intrusion of shallow dikes. Precise relative relocations of these earthquakes $(9,10)$ define narrow ribbons interpreted to mark the highly stressed zone at the top of a vertical tabular magma reservoir. This observation, together with the long wavelength of deformations across the rift system (11), suggests the dilation of a dike-like reservoir that extends from a depth of $3 \mathrm{~km}$ to the prevolcano sea floor, which is depressed to 9- to 10-km depth below sea level. The continuous deformation measured since 1970 on the volcano indicates that the injection of magma into the rift zones is a steady process (11).

Large earthquakes-the 1975 M 7.2 and the 1989 M 6.1 earthquakes-were caused by seaward motion of Kilauea's south flank on a low-angle fault $(12,13)$, which is probably located at the interface between the volcanic edifice and the sea floor. The south flank of Kilauea is associated with high rates of seismicity at depths of 6 to 12 $\mathrm{km}$. Relative relocations (14) show that many of these earthquakes define a low-angle northward dipping fault corresponding to the base of the edifice. Slip on this fault is thought to accommodate the accumulation of magma into the rift zones $(15,16)$. This hypothesis is supported by analysis of geodetic data $(17,18)$. 
For our analysis, we used trilateration, leveling, and sea-level data collected by the Hawaiian Volcano Observatory staff. From 1976 to 1982, trilateration baselines (Fig. 1) show rapid horizontal extension across the rift zones. This extension was particularly fast in the upper southwest and upper east rift zones, reaching a maximum of $26 \mathrm{~cm} /$ year across the summit caldera. Most of the baselines that span the south flank, particularly those perpendicular to the rift zones, experienced compression of up to $9 \mathrm{~cm} / y e a r$. Negligible deformation rates were recorded in the easternmost part of the rift system as well as on the north flank of the volcano. Across Kilauea summit, large horizontal relative displacements were accompanied by subsidence (Fig. 2) at the rift-system axis (up to $7 \mathrm{~cm} /$ year) and uplift (up to $2.5 \mathrm{~cm} /$ year) of the south flank. This uplift was confirmed by tide gauge and water well data (Table 1).

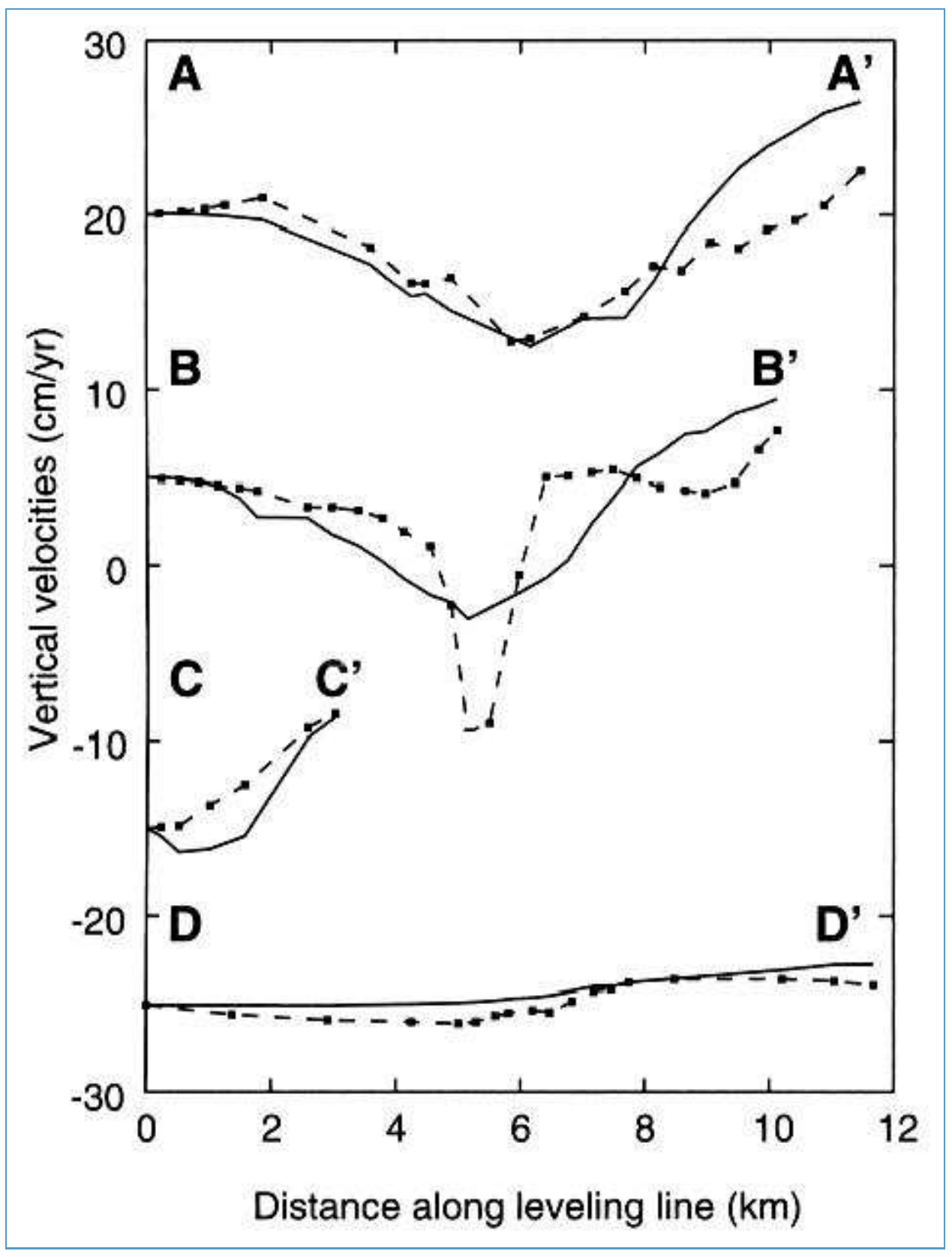

Fig. 2. Comparison of relative vertical velocities measured and predicted by the best fitting model. Data are represented by dots and dashed lines; the best model results are represented by solid lines. AA', Kilauea's summit, projected onto a line trending $\mathrm{N} 165^{\circ} \mathrm{E}$, leveled in April 1976 and October 1982. BB', southwest rift zone, projected $\mathrm{N} 110^{\circ} \mathrm{E}$, leveled in May 1976 and October 1982. CC', upper east rift zone, projected N180E, leveled in May 1976 and August 1982. DD', lower east rift zone, projected N155 ${ }^{\circ} \mathrm{E}$, leveled in July 1976 and December 1982. For locations of level profiles, see figure $7 \mathrm{a}$ of (17). Random error on leveling is taken as $7 \mathrm{~mm} / \mathrm{km}^{1 / 2}(31)$. 


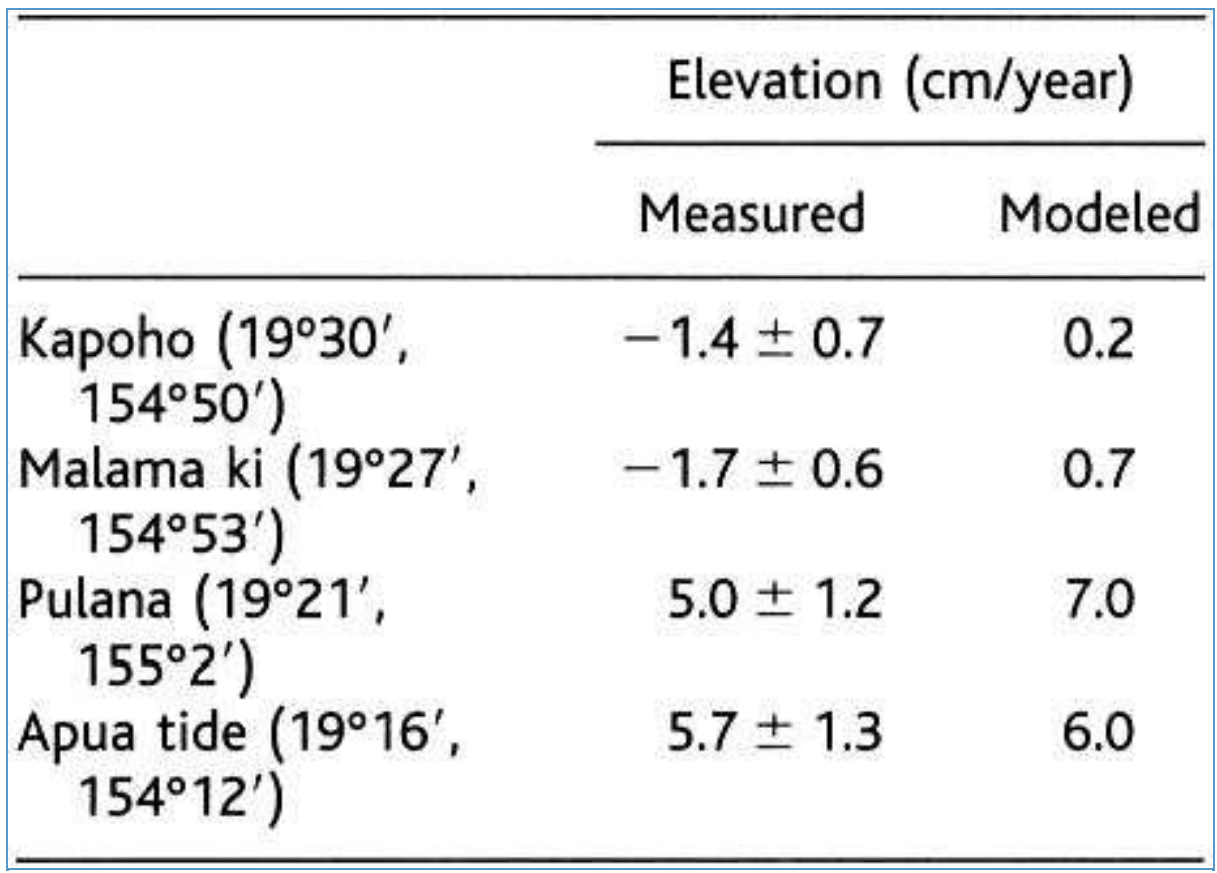

Table 1. Comparison between elevation changes measured in water wells and tide gauges between 1976 and 1982. Water well and tide gauge (Apua) data are derived from the interpolation given in (3).

We analyzed the observed deformation using a three-dimensional mixed boundary element method that takes the topography into account (19). The medium is assumed to be elastic. We further assume that the sporadic shallow dike intrusions and the steady magma-reservoir dilation can be modeled by a single dike (Fig. 3A). The horizontal position of this dike is defined from the shallow seismicity, and, where available, relocated earthquakes $(9,10)$ were used. The dike was also assumed to be the locus of maximum subsidence determined by leveling. In order for the dike to induce fault displacements, it must extend to the low-angle fault at the volcano base. In our starting model, the fault is located at 9-km depth and allowed to slip over a narrow area corresponding to the aseismic region south of the rift zones (Fig. 1). The lack of seismicity there might be related to aseismic creep of the fault caused by elevated temperatures in the rift system of hot olivine-rich magma and olivine cumulates (20). The dip of this fault is assumed to be $5^{\circ}$ to the north-west, which is a good compromise between various independent estimates $(14,21,22)$. The boundary conditions are stresses. All parts of the rift system are assumed to be hydraulically connected, resulting in a single overpressure for the dike. The fault is assumed to move passively in response to the reservoir dilation, and, consequently, it has a null stress perturbation. Young's modulus is 50 GPa, a value deduced from the $P$-wave velocity in the south flank (8) and corrected by a factor of 0.7 to account for the difference between the static and dynamic modulus at a confining pressure of $100 \mathrm{MPa}(23)$. Poisson's ratio is assumed to be 0.25 .
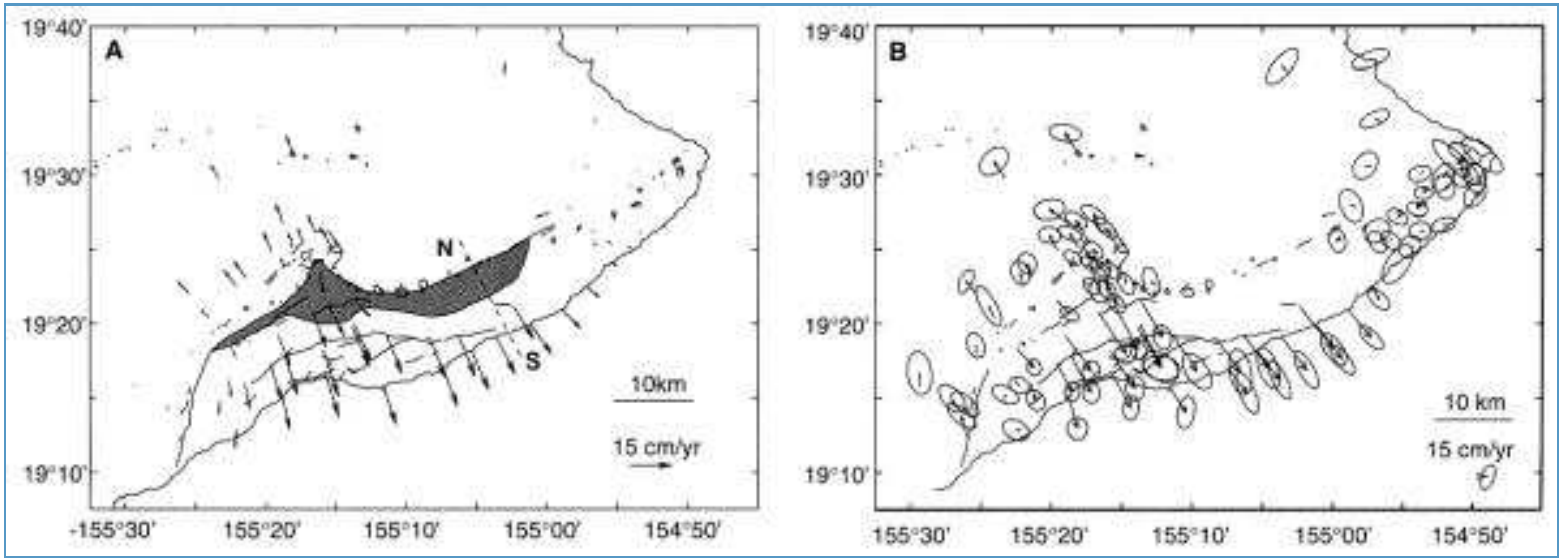

Fig. 3. (A) Velocities predicted by the best fitting model at the trilateration ranging stations. Surface projection of the 
dike modeled is indicated by a bold line and the low-angle fault creeping portion is shown as a gray surface. The rest of the fault is locked. A cross section (N-S) of the model geometry in the east rift zones in represented in Fig. 4. (B) Velocities determined from trilateration data with the model coordinate network adjustment (25) performed with reference to the best-fitting velocity model. Ellipses indicate the $95 \%$ confidence interval.

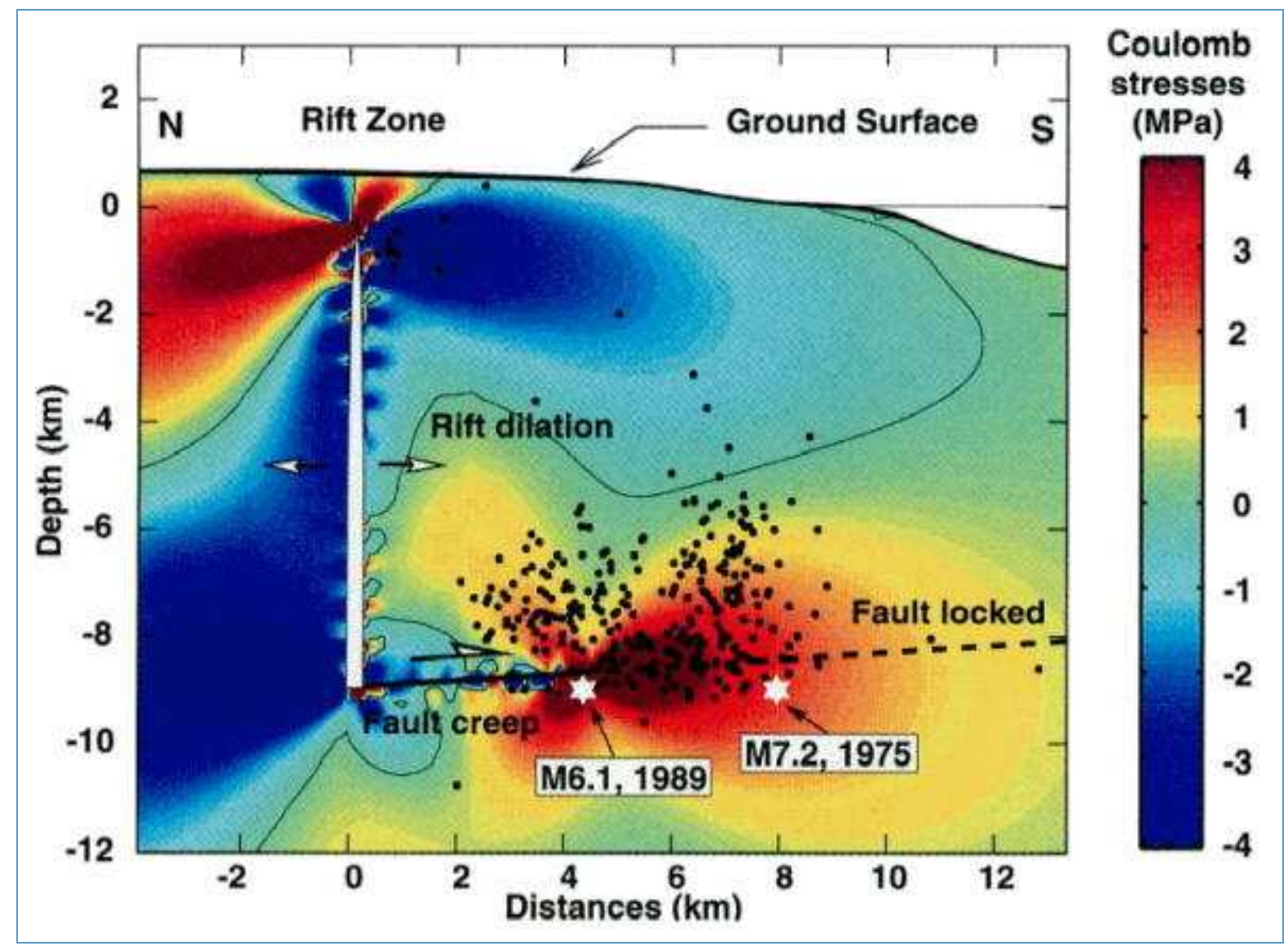

Fig. 4. Coulomb stress changes and $M>=1.5$ earthquakes (black circles) for 1976-82. The vertical cross section goes through the east rift zone (Fig. 3). The creeping portion of the fault is represented by a solid line and the locked portion is represented by a dashed line. Rift-dike overpressure is $9 \mathrm{MPa}$. Coulomb stresses (30) correspond to the model that best fits the deformation data. Potential failure planes considered are subhorizontal, with a seaward slip direction such that positive Coulomb stress variations indicate promotion of seaward slip.

Model variables for this study are the depth, height, width, dip, and overpressure of the dike; the dip; the depth of the low-angle fault; and the southward width of the creeping portion of this fault. To compare among the different models, we computed the error $\left(\left[\mathrm{chi}^{2}{ }^{2}\right)\right.$ on relative displacements along the trilateration baselines (24). To adjust the indeterminate components of the velocity field, we used the model coordinate method of network adjustment (25).

The depth of the top of the dike, its dip, and the area of fault creep were constrained by the trilateration observations. For a fault depth of $9 \mathrm{~km}$, our best-fit solution (Fig. $3 \mathrm{~A}$ ) corresponds to a vertical dike, $8.5 \mathrm{~km}$ high, dilating at an average rate of $40 \mathrm{~cm} / \mathrm{year}$. The low-angle fault coupled to this dike creeps over the narrow aseismic area south of the rift. At the ground surface, the model results in an average rift-zone opening of $20 \mathrm{~cm} /$ year. The model also gives the best fit of the leveling data (Fig. 2). However, the sharp subsidence along line BB' associated with the August 1981 southwest rift intrusion was not resolved (26). Modeled height changes are also comparable to those obtained from sea-level measurements (Table 1). 
Dike dilation with no fault slip fits the trilateration data but leads to an underestimation (up to $50 \%$ ) of the rift subsidence in the summit area (line AA'). Compared with the best-fit solution, when the fault is allowed to slip over a larger uniform width of $10 \mathrm{~km}$, error [chi] ${ }^{2}$ on distance variation increases by $10 \%$, south flank compression is not accounted for, and the rift subsidence is overestimated by up to $40 \%$ in the summit area. The overestimation of the south flank uplift remains the same when the fault is horizontal.

The trilateration data give little constraint on the fault depths and dike height, as well as the precise western and eastern extent of the dike. Indeed, trilateration data are equally well explained by a fault located in the depth range 6 to $11 \mathrm{~km}$ and for a rift system $4 \mathrm{~km}$ shorter or longer to the west or to the east.

This model, with a narrow-creeping fault leading to substantial displacements of the north flank stations, differs from models obtained for 1983-91 (17) and for 1990-93 (18). The previous models used much wider zones of fault slip $(15$ to $30 \mathrm{~km})$ and yielded negligible displacements north of the rift zones. These differences can be partly explained by differences in the pattern of deformation for the different periods: During the 1976-82 period, the south flank experienced compression, whereas extension was recorded after 1983. They also result from the type of data used. We used trilateration measurements, and no site was distant enough to be removed from volcanic activity as is the case with later data from the Global Positioning System. Consequently, our model addresses the deformations and not the absolute displacements of the volcano.

The average rate of rift opening determined in this study (40 cm/year) summed over the 1976-82 period is consistent with the dike opening measured at the onset of the Pu'u O'o 1983 eruption $(2.1 \mathrm{~m})$. This suggests that the 1983 eruption may have been caused by the propagation to the ground surface of a dike-like reservoir that had been inflating since the 1975 earthquake. The observation that the south flank was under compression indicates that rift dilation was not passive but was driven by magma accumulation. The modeled rift dilation implies a magma storage rate of $0.18 \mathrm{~km}^{3} / y$ ear. Compared with storage rate, the volume of erupted magma during this period $(0.006$ $\mathrm{km}^{3} /$ year) was insignificant (27). The predominance of rift magma storage over eruptions can be attributed to the 1975 earthquake, which generated a trapping stress favoring intrusions (16). These observations lead us to conclude that the 1983 eruption is the direct consequence of the high rate of magma storage that took place within the rift zones since 1975.

From 1976 through 1982, the storage and erupted volumes give a total magma supply rate of $0.19 \mathrm{~km} /$ year. Similarly, on the basis of rates of stored and erupted magma, the total magma supply rate ranges from 0.14 to 0.18 $\mathrm{km}^{3} /$ year for $1983-91$ and is estimated to $0.18 \mathrm{~km}^{3} /$ year for $1961-70$ (28). Thus, the rate of magma supplied to the volcano from 1961 to 1991 appears to be constant. This supply rate is nearly twice as large as the rate $(0.1$ $\mathrm{km}^{3} /$ year) estimated from rates of lava produced during large eruptions associated with no summit deformations (29). It is also twice as large as estimated $\left(0.09 \mathrm{~km}^{3} /\right.$ year) from summit inflation and subsidence at the time of rift intrusions (27). However, these rates were estimates of the minimum supply, as they did not take into account magma supplied to the rift zones with no associated summit deformations.

The rift-dike dilation and associated south flank motion over a narrow area of a low-angle fault provide mechanical explanations for the occurrence of south flank earthquakes away from the rift zones (Fig. 4): (i) The area of fault creep is such that dike dilation results in the largest increase of Coulomb stresses (30) where the south flank microseismicity is the highest, and (ii) the locked portion of the fault in our model corresponds to the area that slipped during the M7.2 1975 and the M 6.11989 earthquakes (12,13). Our model is consistent with the compression of the south flank before 1975 leading to the Kalapana earthquake (15), but it does not account for the 
extension of the south flank that occurred after 1983. The models of Kilauea deformation after 1983 use wide zones of fault creep that appear to be inconsistent with the observed occurrence of large earthquakes within rapidly creeping regions $(17,18)$.

\section{References and Notes}

1. P. W. Lipman, J. P. Lockwood, R. T. Okamura, D. A. Swanson, K. M. Yamashita, U.S. Geol. Surv. Prof. Pap. 1276, 1 (1985). SFXI Document Delivery I [Context Link]

2. Between June 1976 and December 1982, 24 intrusion events occurred, but only 5 led to eruptions. [Context Link]

3. P. T. Delaney et al., J. Geophys. Res. 103, 18003 (1998). [Context Link]

4. R. S. Fiske and W. T. Kinoshita, Science 165, 341 (1969). [Context Link]

5. F. W. Klein, R. Y. Koyanagi, J. S. Nakata, W. R. Tanigawa, U.S. Geol. Surv. Prof. Pap. 1350, 1019 (1987). SFXI Document Delivery l [Context Link]

6. T. L. Wright and R. S. Fiske, J. Petrol. 12, 1 (1971). [Context Link]

7. P. D. Hill and J. J. Zucca, U.S. Geol. Surv. Prof. Pap. 1350, 903 (1987). SFX | Document Delivery | [Context Link]

8. P. G. Okubo, H. M. Benz, B. A. Chouet, Geology 25, 867 (1997). [Context Link]

9. D. Gillard, A. M. Rubin, P. Okubo, Nature 384, 343 (1996). Ovid Full Text $\mid$ SFX | Bibliographic Links $\mid$ [Context Link]

10. A. Rubin, D. Gillard, J. L. Got, J. Geophys. Res. 103, 10003 (1998). SFX | Bibliographic Links | Document Delivery | [Context Link]

11. P. T. Delaney, R. S. Fiske, A. Miklius, A. T. Okamura, M. K. Sako, Science 247, 1311 (1990). SFX|

Document Deliveryl [Context Link]

12. M. Ando, J. Geophys. Res. 84, 7616 (1979). SFX | Document Delivery | [Context Link] 
13. W. P. Chen, J. Nabelek, M. A. Glennon, Eos 71, 562 (1990). SFX| Document Delivery l [Context Link]

14. J. L. Got, J. Fréchet, F. W. Klein, J. Geophys. Res. 99, 15375 (1994). [Context Link]

15. D. A. Swanson, W. A. Duffield, R. Fiske, U.S. Geol. Surv. Prof. Pap. 963, 963 (1976). SFX| Document Delivery | [Context Link]

16. J. H. Dieterich, J. Geophys. Res. 93, 4258 (1988). [Context Link]

17. P. T. Delaney, A. Miklius, T. Árnadóttir, A. T. Okamura, M. Sako, J. Geophys. Res. 98, 17801 (1993). SFXI Bibliographic Links | Document Delivery I [Context Link]

18. S. Owen et al., Science 267, 1328 (1995). [Context Link]

19. V. Cayol and F. H. Cornet, J. Geophys. Res. 103, 18025 (1998). [Context Link]

20. D. A. Clague and R. P. Delinger, Bull. Volcanol. 56, 425 (1994). [Context Link]

21. R. S. Crosson and E. T. Endo, Tectonics 1, 495 (1982). SFX I Document Delivery | [Context Link]

22. C. H. Thurber and A. E. Gripp, J. Geophys. Res. 93, 4271 (1988). SFX | Document Delivery I [Context Link]

23. C. H. Cheng and D. H. Johnston, Geophys. Res. Lett. 8, 39 (1981). SFX| Document Delivery | [Context Link]

24. The error is defined as the weighted sum-of-square residual EQUATION where $n$ is the number of baselines, $d^{\text {obs }}$ and $d_{i}^{\text {mod }}$ are the observed and modeled relative displacements, respectively, and [sigma ${ }_{i}^{2}$ are the measurement errors. By using the relative displacements rather than displacement vectors derived from relative displacements, we ensure that the influence of anomalous measurements remains confined to the baselines. [Context Link]

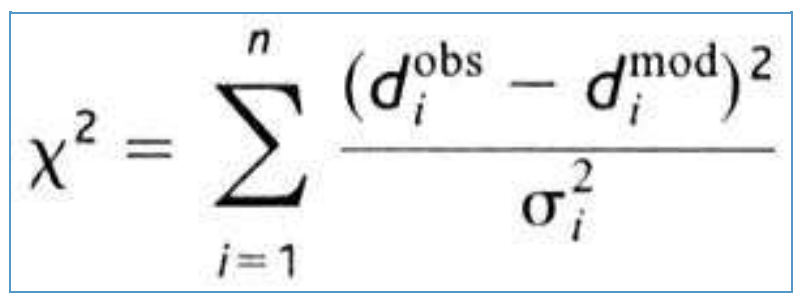

Equation 1 
25. This method [P. Segall and M. V. Matthews, J. Geophys. Res. 93, 14954 (1988) SFX| Document Delivery l] consists of adjusting the unknown rigid body motion of the velocity field with reference to an assumed deformation model. [Context Link]

26. This sharp subsidence in level profile BB' is associated with surface cracking that occurred during the August 1981 southwest intrusion. The discontinuity of the profile cannot be explained by a simple dike model and is attributed to inelastic deformations and faulting [D. D. Pollard, P. T. Delaney, W. A. Duffield, E. T. Endo, A. T. Okamura, Tectonophysics 94, 541 (1983) SFXI Document Delivery $]$. As our study focuses on the deep magma system, we did not attempt to model this event. [Context Link]

27. D. Dzurisin, R. Y. Koyanagi, T. T. English, J. Volcanol. Geotherm. Res. 21, 177 (1984). SFX| Document Delivery | [Context Link]

28. Rates of volume increase due to rift dilation are estimated to $0.025 \mathrm{~km}^{3} /$ year for $1983-91$ (17) and to 0.06 km³ear for 1990-93 (18). From February 1983 to June 1984, lava had been erupted at an average rate of 0.12 km³/year [E. W. Wolfe et al., U.S. Geol. Surv. Prof. Pap. 1350, 471 (1987) SFXI Document Delivery l]. Assuming that this rate remained constant after June 1984, the total rate of magma supplied between February 1983 and 1991 ranges from 0.145 to $0.18 \mathrm{~km}^{3} /$ year. Similarly, for $1961-70$, the eruption rate is $0.042 \mathrm{~km}^{3} /$ year (27), and rates of south flank displacements are $15 \mathrm{~cm} /$ year (29). Assuming that rift deformation mechanisms for 1961-70 were similar to those for $1976-82$, we obtain an injection rate of $0.135 \mathrm{~m}^{3} /$ year. This gives a total magma supply rate for 1961 to 1970 of $0.177 \mathrm{~km}^{3} /$ year. [Context Link]

29. D. A. Swanson, Science 175, 169 (1972). SFX I Document Delivery I [Context Link]

30. Coulomb stress changes are defined as [DELTA]S = [DELTA][tau] - $\mu$ '[DELTA][sigma], where [DELTA][tau] is the shear stress change on a given failure plane (positive in the direction of fault slip), [DELTA][sigma] is the change in effective normal stress (positive in compression), and $\mu^{\prime}$ is the effective friction coefficient $=0.35$. [Context Link]

31. P. T. Delaney, A. Miklius, T. Ámadóttir, A. T. Okamura, M. Sako, U.S. Geol. Surv. Open File Rep. 94-567 (1994). [Context Link]

32. We thank the staff of the Hawaiian Volcano Observatory for providing us with the data; P. Okubo and M. Lisowski for useful discussions; P. Okubo for the earthquake summary data; P. Delaney, P. Segall, S. Owen, R. Simpson, and W. Prescott for very useful comments on this manuscript; and P. Segall for the program for computing trilateration station displacements. This research was supported by the U.S. Geological Survey Volcano Hazards Program. 


\section{GALERIE D'IMAGES}

\section{Sélectionner Tout}

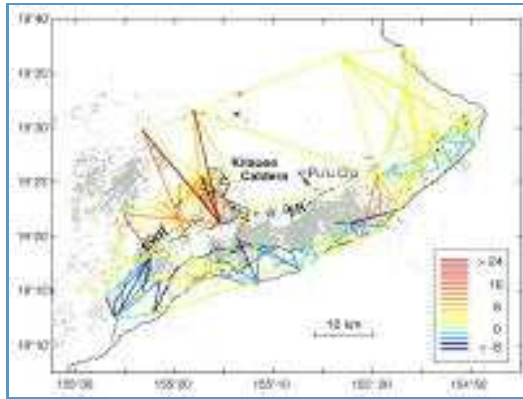

Г Fig. 1

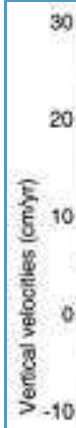

है 10

A
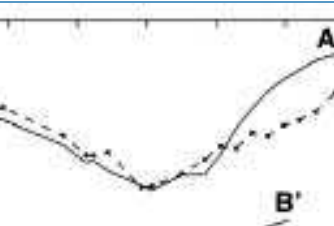

$\therefore$

$-20-$
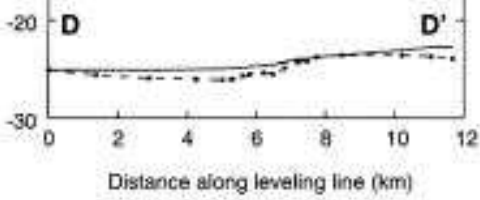

Exporter la sélection vers PowerPoint

Г Fig. 2

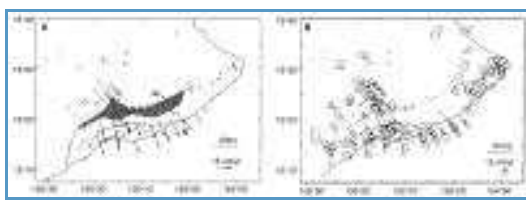

Г Fig. 3

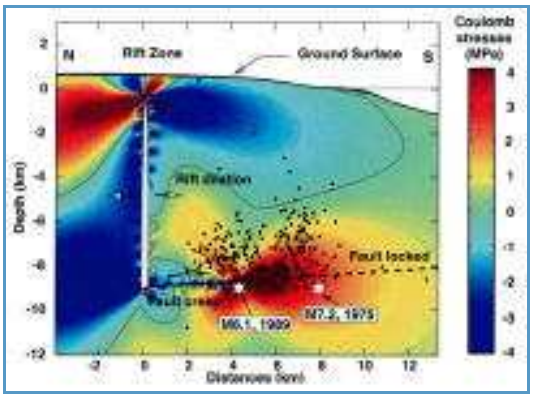

$$
\chi^{2}=\sum_{i=1}^{n} \frac{\left(d_{i}^{\text {obs }}-d_{i}^{\text {mod }}\right)^{2}}{\sigma_{i}^{2}}
$$

Г Fig. 4

Retour au début

Copyright (c) 2000-2009 Ovid Technologies, Inc.

Tout accès ou utilisation d'OvidSP implique que vous acceptez de respecter les termes et conditions, ainsi que toutes les lois afférentes. Si vous n'êtes pas d'accord avec ces termes vous ne devez pas utiliser ce site.

Version: OvidSP_UI02.03.00.130, SourcelD 45290 